\title{
Origin and age of carbonate clasts from the Lusi eruption, Java, Indonesia
} \author{
Andrea Moscariello ${ }^{a}$, Damien Do Couto ${ }^{a}$ \\ a Department of Earth Sciences, University of Geneva, Rue des Maraîchers 13, 1205 Geneva, Switzerland \\ ${ }^{\mathrm{b}}$ Centre for Earth Evolution and Dynamics, University of Oslo, Sem Scelandsvei 2A, 0371 Oslo, Norway \\ ${ }^{\mathrm{c}}$ Department of Geosciences, University of Fribourg, Chemin du Musée 6, 1700 Fribourg, Switzerland
}

Elias Samankassou ${ }^{\mathrm{a}, *}$, Adriano Mazzini ${ }^{\mathrm{b}}$, Massimo Chiaradia ${ }^{\mathrm{a}}$, Silvia Spezzaferri ${ }^{\mathrm{c}}$,

\begin{abstract}
Deep stratigraphic constrains below the Indonesian Lusi mud eruption are currently lacking due to the absence of deep wells and good quality seismic data. A collection of carbonate clasts has been sampled from the Lusi site, active since its birth in 2006. These specimens are part of a large variety of lithotypes erupted from the main crater. The carbonates analysed comprise scleractinian coral and bivalve shell fragments, probably shallowwater in origin, and clasts consisting of planktonic foraminifera-bearing mudstone, from pelagic deposits. Selected rocks were analysed using planktonic foraminifera and ${ }^{87} \mathrm{Sr} /{ }^{86} \mathrm{Sr}$ dating with the aim to constrain their age and to improve the understanding of the, so far unknown, sequence of limestone deposits inferred at this site.

Based on biostratigraphy using planktonic foraminifera, one group of samples reveal to belong to the Planktonic Foraminifera Zone M5b, with an age comprised between 16.29 and 15.10 Ma (Miocene, Latest Burdighalian to Langhian). The Sr isotope-based ages of clasts analysed for ${ }^{87} \mathrm{Sr} /{ }^{86} \mathrm{Sr}$ cover a larger time window spanning from Pliocene (Zanclean and Piacenzian), Miocene (Messinian) down to Eocene (Priabonian). The Pliocene and Messinian ages are unreasonably young from what is known of the local geology and one sample provided an ${ }^{87} \mathrm{Sr} /{ }^{86} \mathrm{Sr}$ age that is $\sim 8 \mathrm{My}$ younger compared to that obtained from the planktonic foraminifera assemblage occurring in that sample. The discrepancy suggests that this and the other unduly young samples have possibly been contaminated by geological materials with radiogenic $\mathrm{Sr}$ isotope composition. The minimum age of $37.18 \mathrm{Ma}$ obtained by ${ }^{87} \mathrm{Sr} /{ }^{86} \mathrm{Sr}$ from a well-preserved oyster shell indicates that some of the clasts can be attributed to the deep seated Ngimbang Formation.

The dating has been combined with the interpretation of seismic profiles to investigate the stratigraphy of inferred carbonates below Lusi and the PRG-1 well located some kilometres to the north east. PRG-1 borehole data are also integrated and discussed in this study.

The obtained results reveal multiple implications: a) the Tuban and Kujung Formations are overlapping at Lusi site; b) the Lusi feeder conduit brecciated and mobilized to the surface carbonate lithologies buried as deep as possibly $\sim 3.8 \mathrm{~km}$ as well as even older and deeper seated lithotypes from the Ngimbang Formation; c) since the deeper carbonate samples erupted in 2006 belong to the typically not overpressured Kujung Formation, an additional overpressure generated from deeper units (Ngimbang Formation) would be required to force these fragments to surface.
\end{abstract}

\section{Introduction}

The current stratigraphic scheme of east Java is based on several studies largely based on information acquired through industry seismic surveys and wells for hydrocarbon exploration (Matthews and Bransden, 1995; Kusumastuti et al., 2002; Satyana, 2005; Sharaf et al., 2005; Ardhana, 1993). The general stratigraphy may vary depending on the selected location as sedimentation can be affected by the presence of e.g. neighbouring volcanic complexes, extension of carbonate platforms, localized reefal buildups and lacustrine deposits. Seismic acquisition is typically arduous due to the logistics occurring in densely populated areas such as the NE Java. In addition the signal in seismic profiles is often buffered by the presence of carbonate units that absorb large part of the energy. This results in poor resolution of the internal structures of numerous onshore carbonate units and formations, as well as limited or no details about the overlaid formations. Similarly the available well data is restricted to shallow depths (i.e. sand reservoirs $<1 \mathrm{~km}$ ) or reach the top of the reefal carbonates that are the

\footnotetext{
* Corresponding author.

E-mail address: Elias.Samankassou@unige.ch (E. Samankassou).
} 

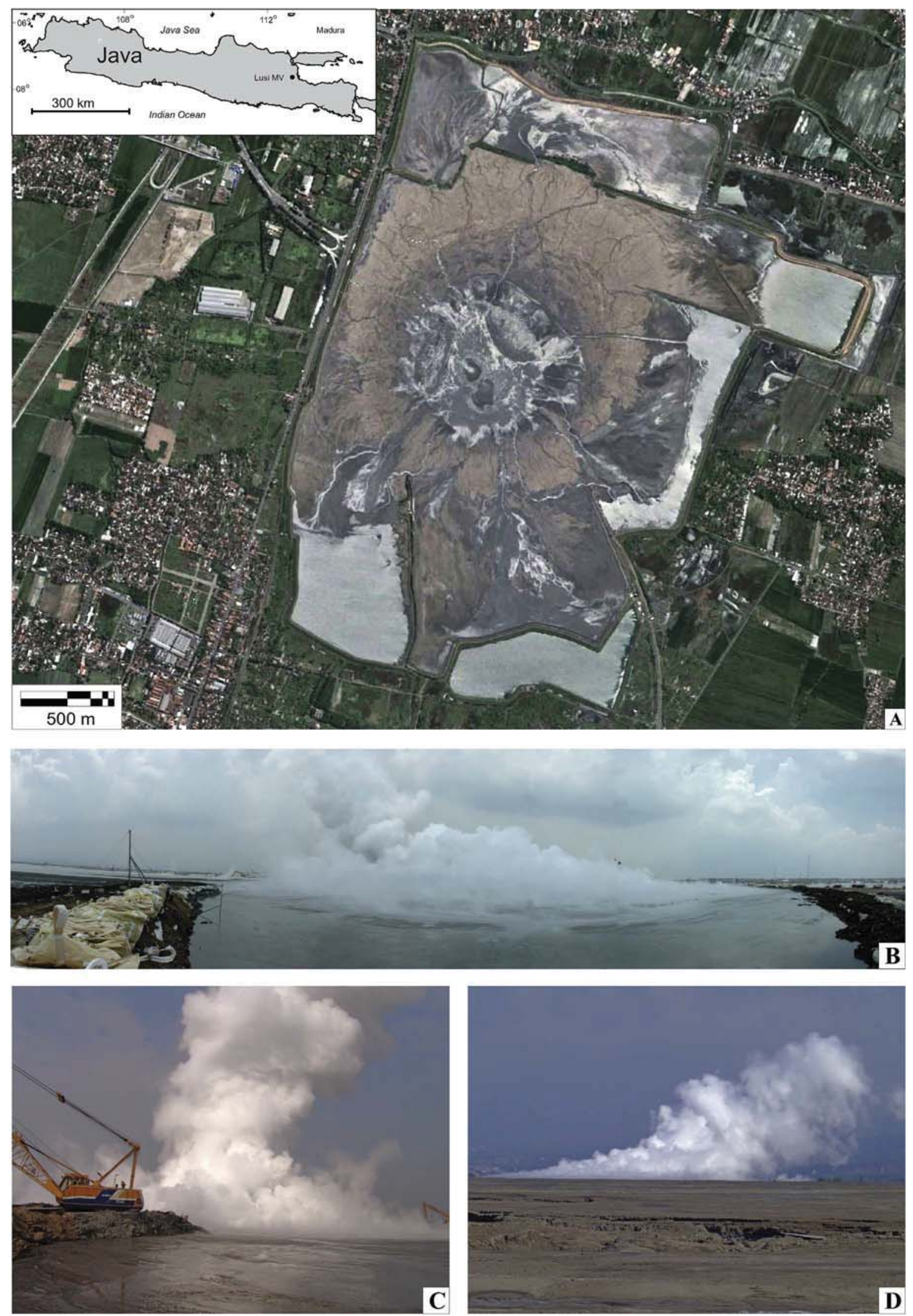

Fig. 1. Setting.

Inset map of Java Island, Indonesia with the marked position of the Lusi eruption site in northeast Java. (A) Satellite image of the Lusi eruption site showing the two active vents in the central part and the vast area covered by erupted mud breccia framed by a tall embankment wall. In brown colour the dry mud breccia zone that is today accessible. Field images of the Lusi crater framed by an artificial berm (B) that allowed the direct use of excavators for fluids and clasts sampling. (C) Sampling using an excavator in 2006. (D) Since 2009 the Lusi crater remained isolated inside a $7 \mathrm{~km}^{2}$ embankments zone surrounded by a vast area of erupted mud breccia that is dry on the outskirts. (For interpretation of the references to colour in this figure legend. the reader is referred to the web version of this article.) 
common reservoir units in the NE Java Basin (e.g. Kusumastuti et al., 2002). The approach proposed in this paper is to obtain information about deeply buried strata exploiting the available piercement structures. These localities may be considered as "free wells" since during their growth and eruptive activity, piercements brecciate the formations intersected by the feeder channel and ultimately expel to the surface a mix of the different lithologies. The study of erupted mud breccia clasts, collected at mud volcano craters, was successfully used to reconstruct the pierced stratigraphic column. Examples of such studies are reported in the literature (e.g. Premoli Silva et al., 1996; Akhmanov et al., 2003; Giresse et al., 2010; Gennari et al., 2013). This technique may be also used at the Lusi locality in the north east Java. Lusi is one of the most spectacular geological phenomena currently active on Earth. This clastic-dominated geysering-like system started the 29th May 2006 in the Sidoarjo regency and has been active since, erupting a current average of $80,000 \mathrm{~m}^{3}$ of mud breccia per day (Mazzini et al., 2007, 2012; Karyono et al., 2016) (Fig. 1). A collection of the clasts erupted at Lusi reveals the presence of organic-rich shales, volcaniclastic rocks, and carbonate specimens. These lithologies correspond to the known stratigraphy present below Lusi. Here the section up to $\sim 2833 \mathrm{~m}$ depth is constrained by drilling results (e.g. see drilling details in Lupi et al., 2014), and consists of:

1) Recent Holocene alluvial sediments (intercalated sands and clay) between 0 and $290 \mathrm{~m}$. 2) Pleistocene alternating sandstone and shale of the Pucangan Formation, between 290 and 900 m. 3) Pleistocene bluish gray clay of the Upper Kalibeng Formation, between 900 and $1871 \mathrm{~m}$. This unit is strongly illitized and partly organic rich. 4) volcaniclastic deposits between $1871 \mathrm{~m}$ and at least up to $\sim 2833 \mathrm{~m}$, but likely deeper. 5) inferred Miocene-Oligocene carbonates of the Tuban and Kujung (including the upper Prupuh unit) Formation assumed to be as deep as 3800 m. 6) Eocene - Early Oligocene (?) black shale of the Ngimbang regional source rock deeper than $\sim 3800 \mathrm{~m}$ (Mazzini et al., 2007, 2012; Istadi et al., 2009; Sawolo et al., 2009).

The stratigraphy below $2833 \mathrm{~m}$ has not been penetrated and it remains under investigation. So far, the exact depth of the boundary between the volcaniclastic deposits and the overlaid carbonates is not constrained by direct data. Similarly, the age of the carbonates remains unclear. The knowledge of East Java carbonates is inferred from data obtained from the northern part of the basin (Kendeng Deep to the north, including present East Java Sea) where most petroleum companies have operated. Porong-1 well (PRG-1), as well as KE-11C, KE-11E BD-1 wells are the only sites/wells penetrating carbonates of East Java located to the south of Kendeng Deep (Kusumastuti et al., 2002). Therefore, new samples from carbonate formations, such as those collected at Lusi, may provide additional information to constrain ages and to better understand the regional paleogeography. Interpreting the information from other localities, the carbonate underneath Lusi have been ascribed to a) the platform limestones of the Oligocene Kujung Formation, similarly to those present in the offshore East Java Basin, and/or b) to the younger early middle Miocene reefal Prupuh Unit or c) even younger carbonates occurring on top of the Tuban Formation (and their slope and basinal equivalent). The presence of the Tuban Formation is suggested based on Sr dating of one red algae fragment recovered from the inferred structurally similar carbonates drilled in the Porong-1 well (located in the same region). Results from PRG-1 well indicate a numerical age of approximately $16 \mathrm{Ma}$ (late early Miocene) (Kusumastuti et al., 2002). The only dating that has been completed at Lusi so far is reported in Mazzini et al. (2007) and in Sawolo et al. (2009) that compared the dating of foraminifera and nannofossils from the mud erupted at Lusi site during its initial activity with side well cores from the BJP-1 exploration well located in the vicinity. Results revealed that large part of the mud originates from the Kalibeng Formation between 1.2 and $1.8 \mathrm{~km}$, although a deeper source was never excluded. Since the initiation of the Lusi eruption no further attempts have been made to date the mud or the clasts present in the erupted mud breccia.

Since the Lusi birth in 2006 we have conducted a systematic collection of different lithologies of mud breccia clasts erupted from the Lusi crater site. These include also specimens of carbonate samples that are the primary focus of this study. The aim of this paper is to date the clasts selected from the collection of carbonate lithologies and to a) constrain the stratigraphy and the local basinal history and b) improve our understanding of the Lusi plumbing system discussing how the obtained ages fit the current stratigraphic scheme of the area obtained from available seismic data, outcrops and cores.

\section{Setting}

The eruption site in East Java nicknamed Lusi is an active sedimenthosted hydrothermal system that has been active since the 29th of May 2006 (Mazzini et al., 2012; Miller and Mazzini, 2017). It is located in a Cenozoic-aged back-arc basin of NE Java (Kusumastuti et al., 2000). Currently a surface of nearly $7 \mathrm{~km}^{2}$ is covered by erupted mud breccia (Fig. 1). This area is framed by a $10 \mathrm{~m}$ tall embankment that prevents additional floods in the surrounding villages. The vast walkable area inside the Lusi embankment zone is filled by erupted dry mud breccia consisting of a fine grained sediments (from clay up to sand) and clasts of different sizes (up to $15-20 \mathrm{~cm}$ ) and lithologies.

\section{Methods}

\subsection{Field sampling}

The eruption of mud breccia characterized the Lusi activity after its birth in 2006. Since then we have conducted sampling of erupted mud breccia clasts of different lithologies. During the first years we collected sediments from the scoop of excavators that could access and collect material directly from the crater area. Later we handpicked specimens from the vast area of walkable dry mud breccia that surrounds the central active zone.

From this collection, we selected 12 samples for dating (Table 1) using ${ }^{87} \mathrm{Sr} /{ }^{86} \mathrm{Sr}$ ratios and for thin sections used for microfossil identification.

\subsection{Sample preparation}

Samples for $\mathrm{Sr}$ isotope analyses were recovered by micro-drilling targeted portions of rock slabs made from carbonate specimens. About $10 \mathrm{mg}$ of powdered carbonate material were dissolved in $2.2 \mathrm{M}$ high purity acetic acid during $1-2 \mathrm{~h}$ at room temperature in conical shaped $2 \mathrm{ml}$ vials. The solutions were centrifuged and the supernatant was recovered and transferred to Teflon vials, where it was dried down on a hot plate. The residue was re-dissolved in a few drops of $14 \mathrm{M} \mathrm{HNO}_{3}$ and dried down again before Sr separation from the matrix using SrSpec resin. The Sr separate was dissolved again in $5 \mathrm{ml}$ of $\sim 2 \% \mathrm{HNO}_{3}$ solutions and ratios were measured using a Thermo Neptune PLUS Multi-Collector ICP-MS in static mode. The ${ }^{88} \mathrm{Sr} /{ }^{86} \mathrm{Sr}(8.375,209)$ ratio was used to monitor internal fractionation during the run. Interferences at masses $84\left({ }^{84} \mathrm{Kr}\right), 86\left({ }^{86} \mathrm{Kr}\right)$ and $87\left({ }^{87} \mathrm{Rb}\right)$ were also corrected in-run by monitoring ${ }^{83} \mathrm{Kr}$ and ${ }^{85} \mathrm{Rb}$. The SRM987 standard was used to check external reproducibility, which was $10 \mathrm{ppm}$ (1SD) on the long-term (more than 100 measurements during one year). The internally corrected ${ }^{87} \mathrm{Sr} /{ }^{86} \mathrm{Sr}$ values were further corrected for external fractionation (due to a systematic difference between measured and a nominal standard ratio of the SRM987 of ${ }^{87} \mathrm{Sr} /{ }^{86} \mathrm{Sr}=0.710248$ : McArthur et al., 2001 ) by a value of $-0.039 \%$ per amu.

Thin sections of all samples were made for petrographic studies, particularly for screening of possible diagenetic alteration. 

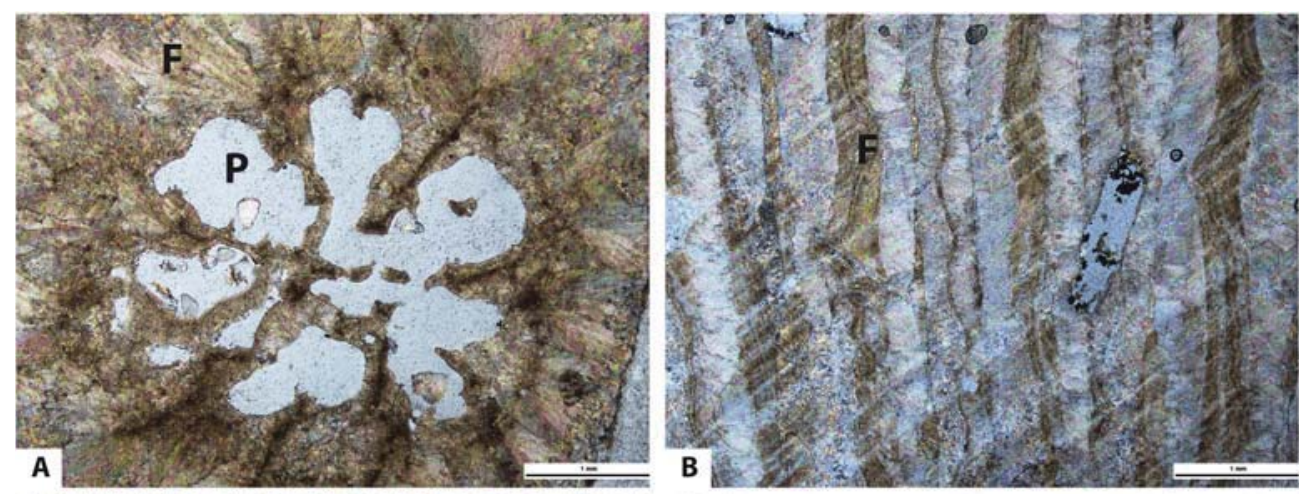

Fig. 2. A- B.: Finger-like scleractinian corals with well-preserved fibrous fans (F) and open pores (P) cut perpendicular to the direction of growth in A and parallel in B. C. Section parallel to direction of growth of the coral skeleton with filled pores (FV). D. Coral skeleton (CS) encrusted by coralline red algae (RA). E. Well-preserved multilayered bivalve (oyster) shell. F. Oyster shell exhibiting borings with micritized walls in dark (arrows). (For interpretation of the references to colour in this figure legend, the reader is referred to the web version of this article.)
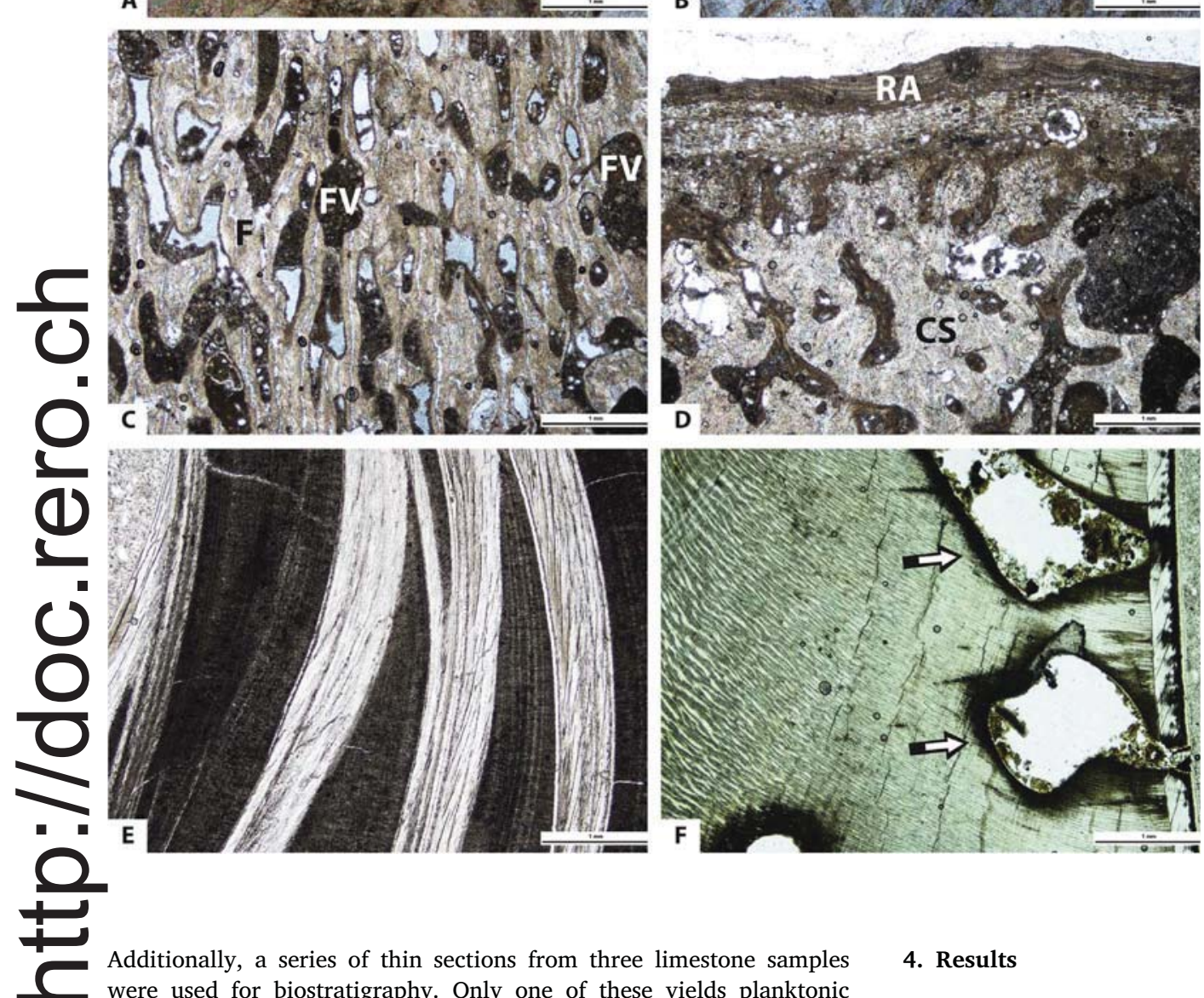

Additionally, a series of thin sections from three limestone samples were used for biostratigraphy. Only one of these yields planktonic foraminifera. Therefore, a total of five thin sections were analysed from that specific sample (JVIII-F). The stratigraphic chart of Wade et al. (2011) was used to derive ages.

\subsection{Seismic profiles}

Time migrated 2D seismic lines passing in proximity of the BJP-1 and Porong-1 wells were interpreted in detail using Petrel platform (Schlumberger) in order to investigate the detailed stratigraphy surrounding the Lusi area. Access to e-logs and check shots data allowed to develop a velocity model and calibrate wells to seismic and calculate the depths of key stratigraphic horizons (for more details see Moscariello et al., 2017). Note that the seismic acquisition was done during the 80 s and 90s, hence well before the occurrence of the Lusi eruption.

\section{Results}

\subsection{Petrography}

The analysed corals show overall a well-preserved skeleton, with visible fibrous fans (Fig. 2A, B and 2C). The pores are empty in some of the corals, and filled with fine-grained material in others (Fig. 2C). In some cases the corals exhibit encrustation by coralline red algae (Fig. 2D). The coral skeleton is too thin to be sampled separately for $\mathrm{Sr}$ dating, implying that some matrix and/or sediment from pore infills were included in the analysed micro-drilled powder.

Except for one ripped form, all the studied bivalves consist of oysters. The shell fragments are well preserved, with distinct alternating layering characteristic of oysters (Fig. 2E). Some of the shells have borings, partly with micritized walls (Fig. 2F). Shells are thick enough and were sampled without matrix. Dark areas, likely impregnated, pore infills and micritized zones were avoided during micro-drilling.

Multiple gastropods were collected. However, the shells of the specimens are too thin to be micro-drilled for $\mathrm{Sr}$ isotope analyses. 


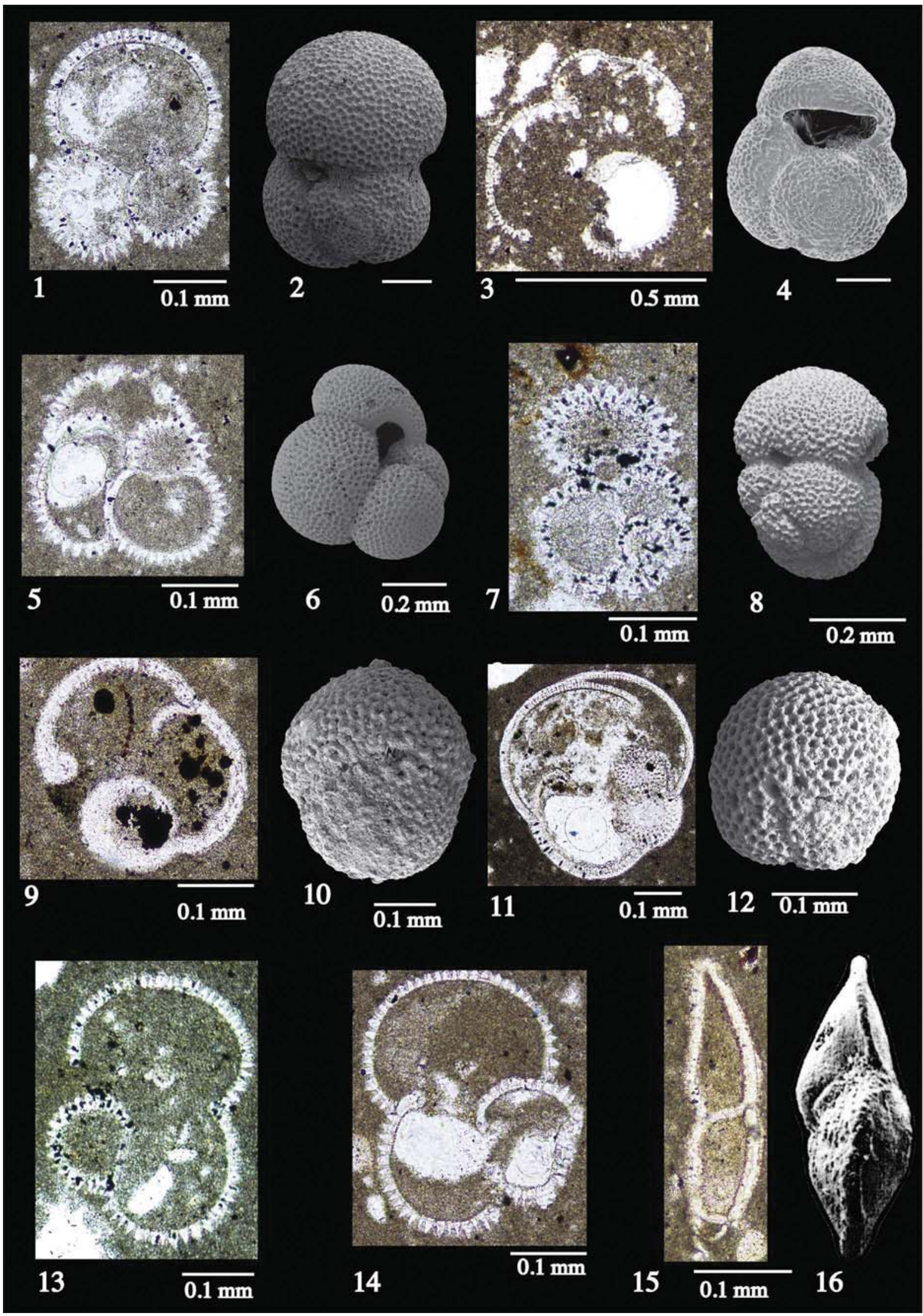

Fig. 3. Planktonic foraminifera from thin section JVIII-F and comparison with whole specimens of the identified species. A. Trilobatus trilobus, sample JVIII-F; B. Trilobatus trilobus, image of the neotype from Rögl (2012); C. Globigerinoides obliquus, sample JVIII-F; D. Globigerinoides obliquus, image of the holotype from Spezzaferri et al. (2017); E. Trilobatus sacculifer, sample JVIII-F; F. Trilobatus sacculifer, sample BC3441, Alboran Sea; G. Globigerinoides ruber, sample JVIII-F; H. Globigerinoides ruber, sample BC3441, Alboran Sea; I. Trilobatus sicanu, sample JVIII-F; J. Trilobatus sicanus, sample IODP-359-36-4-68-70 cm, Maldives K. Praeorbulina glomerosa, sample JVIII-F; L. Praeorbulina glomerosa, sample IODP-359-36-4-68-70 cm, Maldives; M. Globigerinoides cf ruber, sample JVIII-F; N. Globigerinoides cf ruber, sample JVIII-F; H. Globigerinoides ruber, sample JVIII-F; O. Globorotalia sp. belonging to the G. menardii group, sample JVIII-F; P. image of the neotype of G. menardii, from Ellis and Messina (1949). 


\subsection{Biostratigraphy}

Sample JVIII-F (Table 1), consisting of mudstone, yields planktonic foraminifera (Fig. 3). The assemblage contains rare specimens of Globigerinoides and Trilobatus together with specimens that can be attributed to the Globorotalia menardii group. The presence of Trilobatus sicanus and Praeorbulina glomerosa and the absence, in all the investigated thin sections, of specimens that could be clearly attributed to the genus Orbulina (the first occurrence of Orbulina suturalis marks the lower boundary of Zone M6) allow to restrict the age attribution to the interval spanning Zone M5b of Wade et al. (2011). The lower boundary of this Zone is dated as old as $16.29 \mathrm{Ma}$ and its top as old as $15.10 \mathrm{Ma}$ (Wade et al., 2011). The generic attribution of the planktonic species follows Spezzaferri et al. (2015), a purely taxonomic research, based on a robust coupling of fossil and genetic evidence. In particular, the species "sicanus" here attributed to Trilobatus was previously attributed to the genus Praorbulina (P. sicana in, e.g., Wade et al., 2011) or Globigerinoides (Turco et al., 2011). However, according to the International Code of Zoological Nomenclature-ICZN (Ride et al., 2012), the tentative generic combination of a genus with a species name does not affect the availability of the specific name, meaning that a species name remains valid even if the generic name is tentatively changed. Additionally the ICZN consider the principle of homonymy for species name having the same spelling (e.g., the species "sicanus" and "sicana" are homonyms and the one-letter difference is only due to the association with the genus name).

\subsection{Strontium isotope dating}

Table 1 includes ${ }^{87} \mathrm{Sr} /{ }^{86} \mathrm{Sr}$ data of the samples analysed, along with the nature of the material used for measurements. Results reveal a wide time window spanning from 37.18 to 3.14 Ma (Fig. 4). The oldest age was recorded from an oyster shell that gave mean value of $37.18 \mathrm{Ma}$ (Eocene, Priabonian). The other measured shells (Miocene) vary in age from 20.38 Ma (Aquitanian) to 6.10 Ma (Messinian). The foraminiferabearing sample JVIII-F dated with planktonic foraminifera, and another carbonate clast showed an Sr isotope age of 6.1080 and 6.84 Ma respectively. The sclearactinian corals revealed the youngest Pliocene ages (from 4.99 to $3.14 \mathrm{Ma}$, Zanclean and Piacenzian).

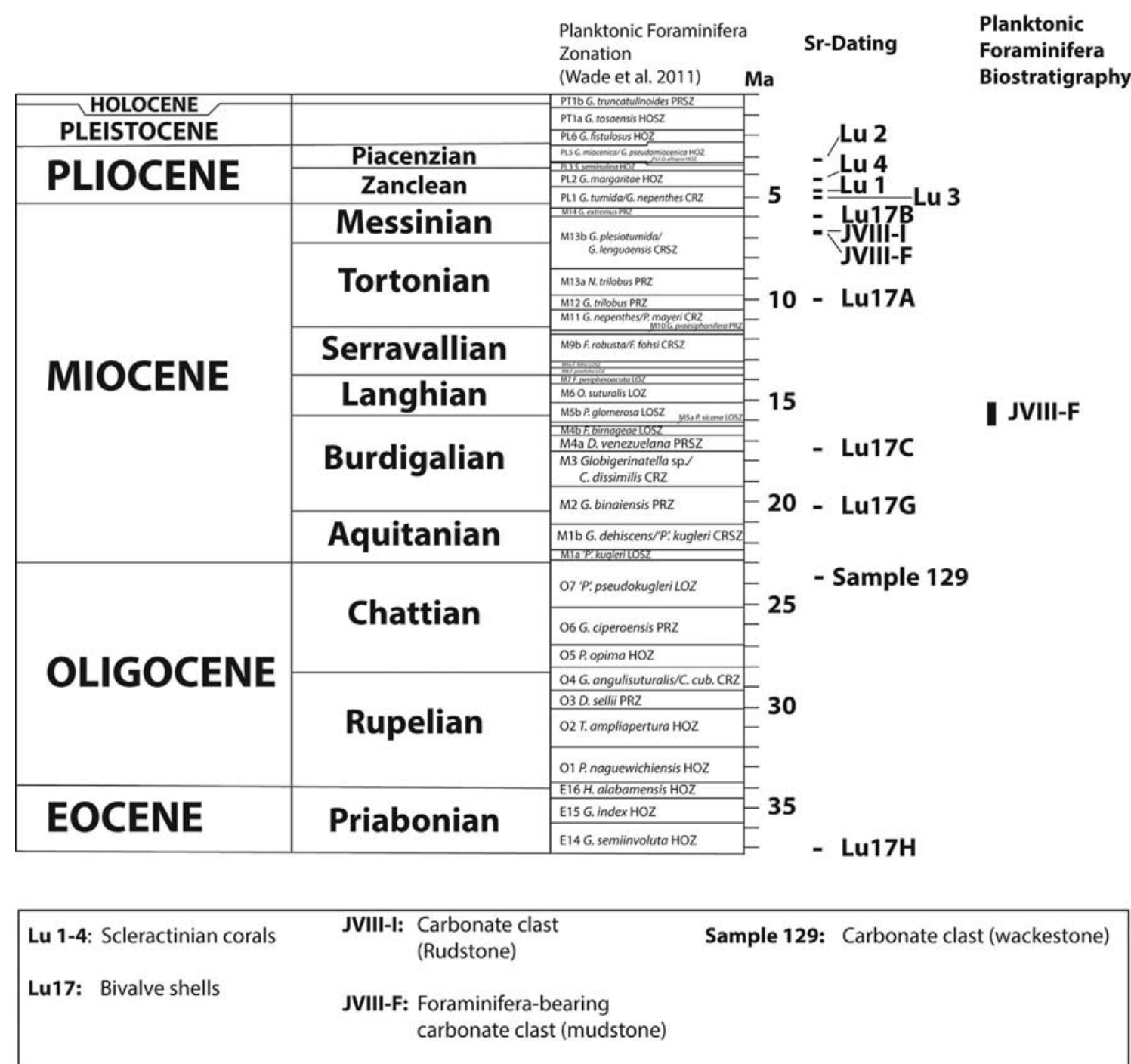

Fig. 4. Stratigraphic position of dated samples on the chronostratigraphic chart. Planktonic Foraminifera Zonation is based on Wade et al. (2011). Sr ages are calculated using McArthur et al. (2001). 
Table 1

${ }^{87} \mathrm{Sr} /{ }^{86} \mathrm{Sr}$ data. Sr ages are calculated using McArthur et al. (2001). Note that the samples indicated as scleractinian corals may include matrix and/or sediment infills. Samples originating from bivalves were micro-drilled from shells only and, thus, can be considered pristine (see text for details and Fig. 2).

\begin{tabular}{|c|c|c|c|c|c|c|}
\hline \multirow[t]{2}{*}{ Sample } & \multirow[t]{2}{*}{ Nature of sample } & \multirow[t]{2}{*}{$87 \mathrm{Sr} / 86 \mathrm{Sr}$} & \multirow[t]{2}{*}{$1 \mathrm{SE}$} & \multicolumn{3}{|c|}{ Age in Ma } \\
\hline & & & & $\min$. & mean & $\max$. \\
\hline Lu1 & Scleractinian coral & 0.709043 & 0.000002 & 4.62 & 4.74 & 4.84 \\
\hline Lu2 & Scleractinian coral & 0.709060 & 0.000002 & 2.88 & 3.14 & 3.46 \\
\hline Lu3 & Scleractinian coral & 0.709036 & 0.000003 & 4.91 & 4.99 & 5.08 \\
\hline Lu4 & Scleractinian coral & 0.709051 & 0.000002 & 3.92 & 4.23 & 4.47 \\
\hline 129 & $\begin{array}{l}\text { Carb. clast } \\
\text { (wackestone) }\end{array}$ & 0.708214 & 0.000002 & 23.60 & 23.77 & 23.93 \\
\hline JVIII-I & Carb. clast (rudstone) & 0.708960 & 0.000001 & 6.69 & 6.80 & 6.94 \\
\hline JVIII-F & Carb. clast (mudstone) & 0.708959 & 0.000004 & 6.72 & 6.84 & 6.98 \\
\hline LU17A & Bivalve (oyster shell) & 0.708885 & 0.000002 & 9.85 & 10.03 & 10.24 \\
\hline LU17B & $\begin{array}{l}\text { Bivalve (ripped, } \\
\text { underm.) }\end{array}$ & 0.708990 & 0.000001 & 6.01 & 6.05 & 6.10 \\
\hline LU17C & Bivalve (oyster shell) & 0.708634 & 0.000002 & 17.33 & 17.44 & 17.54 \\
\hline LU17G & Bivalve (oyster shell) & 0.708416 & 0.000002 & 20.22 & 20.38 & 20.56 \\
\hline LU17H & Bivalve (oyster shell) & 0.707745 & 0.000003 & 36.59 & 37.18 & 37.95 \\
\hline
\end{tabular}

\section{Discussion}

\subsection{Strontium isotope dating and biostratigraphy}

The planktonic foraminifera assemblage of sample JVIII-F provided clear dating results (Zone M5b, between 16.29 and $15.10 \mathrm{Ma}$, topmost Burdigalian to early Langhian). This time window agrees with the current Sr-isotope age of 15.34 Ma (Langhian) obtained from the topmost limestone of a formation interpreted to be Tuban (cf. Sharaf et al., 2005; their Fig. 3) (Fig. 4). The mudstone texture and the presence of planktonic foraminifera indicate a pelagic depositional setting. A comparable depositional setting is reported from the underlying Formation for, e.g., the Prupuh Unit, representing the slope facies equivalent to the shallow-water reefal facies of the Kujung Formation (Satyana, 2005) (Fig. 5). Sharaf et al. (2005) reported a "chalk facies" rich in planktonic foraminifera from the Tuban Formation, likely the equivalent of the planktonic foraminifera-bearing mudstone in our study. Kusumastuti et al. (2002) used a red algal fragment from a sidewall core in the Porong-1 (PRG-1) well (depth of $2586 \mathrm{~m}$ ) to calculate strontium isotopic ages. This sample was collected within $2 \mathrm{~m}$ of the interpreted lithological discontinuity and the results indicated an absolute age of 16 Ma (late early Miocene). This implies that the planktonic foraminifera-bearing sample interpreted to originate from the Tuban Formation in the present study may represent the slope or basinal facies contemporaneous to the shallow-water facies interpreted as Tuban in the Porong-1 well (PRG-1). Another important piece of information is provided by the dating of a sidewall core at $2584 \mathrm{~m}$ in the same PRG-1 well. These samples were collected less than a couple of meters above the sample dated at $16 \mathrm{Ma}$, and were dated biostratigraphically as middle-late Pliocene, about $3 \mathrm{Ma}$. This clearly indicates that this site area was exposed to substantial erosion and/or non-deposition for about 13 Ma (Fig. 5). It is worth noticing that Plio-Pleistocene volcanoclastic deposits were observed in the BJP-1 well from 1871 and at least up to $2833 \mathrm{~m}$ (Fig. 5). These deposits are absent at the PGR-1 well where presumably the Kalibeng Fm (i.e. dated at $3 \mathrm{Ma}$ ) caps directly the thin Tuban and the Kujung Fms. We suggest that the lateral discontinuity of the volcanoclastic deposits is probably ascribed to a laharic (?) event (i.e. from the Arjuno-Welirang volcanic complex) that does not extend further to the NE where the PRG-1 well is located.

The age of sample JVIII-F as derived from $\mathrm{Sr}$ isotopes is unrealistic because the planktonic foraminifera assemblage of the same sample indicates an age that is more than $8 \mathrm{My}$ older (Fig. 3). No evidence of species older than Zone M5b has been found and, therefore, reworking of planktonic foraminifera in sample JVIII-F can be ruled out. A possible reason for this discrepancy is contamination of the investigated carbonate samples by geological material with more radiogenic $\mathrm{Sr}$ isotope composition (e.g., Israelson and Spezzaferri, 1998), which would result in a shift towards younger Sr isotope-based ages. Taking this into account, we estimate that the pristine carbonate material with $\mathrm{Sr}$ isotope composition in equilibrium with that of seawater at the Miocene (i.e. time of its precipitation as indicated by the planktonic foraminifera assemblage) would range between $0.708,776(15.10 \mathrm{Ma})$ and $0.708,702$ (16.29 Ma) (McArthur et al., 2001). Since the investigated sample has an ${ }^{87} \mathrm{Sr} /{ }^{86} \mathrm{Sr}$ value of $0.708,959$, the contaminant material is expected to have a higher ${ }^{87} \mathrm{Sr} /{ }^{86} \mathrm{Sr}$ value. The various clasts entrained in the Lusi feeder conduit form a mud breccia mixture including various lithotypes and multiple fluids from different units and formations. This cocktail of fluids and crushed sediments may indeed alter the isotopic analyses. The bluish gray shales of the Kalibeng Formation (Fig. 4) have ${ }^{87} \mathrm{Sr} /{ }^{86} \mathrm{Sr}$ values $>0.710,129$ (Mazzini et al., 2017) and are the likely candidates to contaminate the Sr isotopic values of the unduly young samples. The ${ }^{87} \mathrm{Sr} /{ }^{86} \mathrm{Sr}$ values of magmatic rocks of the Sunda arc (Java, east of longitude $111^{\circ}$ ) are between 0.704 and $<0.706$ with a main mode at 0.7045 . These values are much lower than the ${ }^{87} \mathrm{Sr} /{ }^{86} \mathrm{Sr}$ values measured in Lusi ( $>0.708$ ) and, therefore, cannot be responsible for a "younging" of the ages, which must be due to a contaminant with more radiogenic ${ }^{87} \mathrm{Sr} /{ }^{86} \mathrm{Sr}$ (see Appendices).

Samples Lu 1 to 4 are all fragments of scleractinian corals, originating from coral-bearing carbonates widely reported from the Java Sea Basin. Strontium dating of these samples indicates Pliocene age (4.99-3.14 Ma Zanclean and Piacenzian). To our knowledge there is no reefal carbonates documented during the Pliocene time. In addition, the Pliocene sediments at the Lusi site consist of volcaniclastics deposits that cannot contain corals (Fig. 5). This implies that the dated corals are in fact older than the Sr-derived Pliocene time. Assuming the same contamination parameters described earlier on, we consider a Sr-isotope shift to younger values and can assign these coral fragments to the Tuban Formation (Figs. 4-5). In theory, however, the Kujung Formation from which coral fragments are also reported (Sharaf et al., 2005) is a potential candidate, too. It is important to notice that potential contamination (from younger sediments) may be exacerbated in particular for coral samples that display higher porosity and may thus facilitate the entrapment of exotic particles (Fig. 2; see also the section on petrography above).

Having established that we have to invoke contaminations for some of the samples, it remains so far unclear if a similar situation is likely for the other carbonate clast samples that reveal Eocene-Priabonian, Oligocene-Chattian and Miocene-Messinian. Contamination appears unlikely in the other dated shells, from which was easier to drill pristine samples.

The overall ages indicate that the carbonates deposits extend for a period including the carbonate platform of the Oligocene Kujung Fm, as well as Miocene reefal upper part of the Kujung Fm, including also the Miocene Tuban Fm characterized by marly shales and limestones.

Of particular interest are the oysters of sample Lu17H, which exhibits the oldest Sr-based age obtained in the present study and that is dated as Priabonian. This stratigraphic level coincides with the depth of the organic-rich Ngimbang Fm. Indeed, lacustrine and marine deposits, including carbonates, were reported from the Ngimbang Formation (Satyana and Darwis, 2001; Mudjiono and Pireno, 2002). Further research is needed to provide more details on facies of this Formation.

\subsection{Insights from seismic profiles}

The findings of the carbonate dating and facies identification have been incorporated in the interpretation of the 2D seismic profiles intersecting carbonates above and in the proximity of the Lusi area. The detailed seismic facies analysis in Lusi region was implemented using composite seismic lines intersecting Lusi and the BJP-1 well and connecting the region pierced by the PRG-1 well, where the seismic signal 


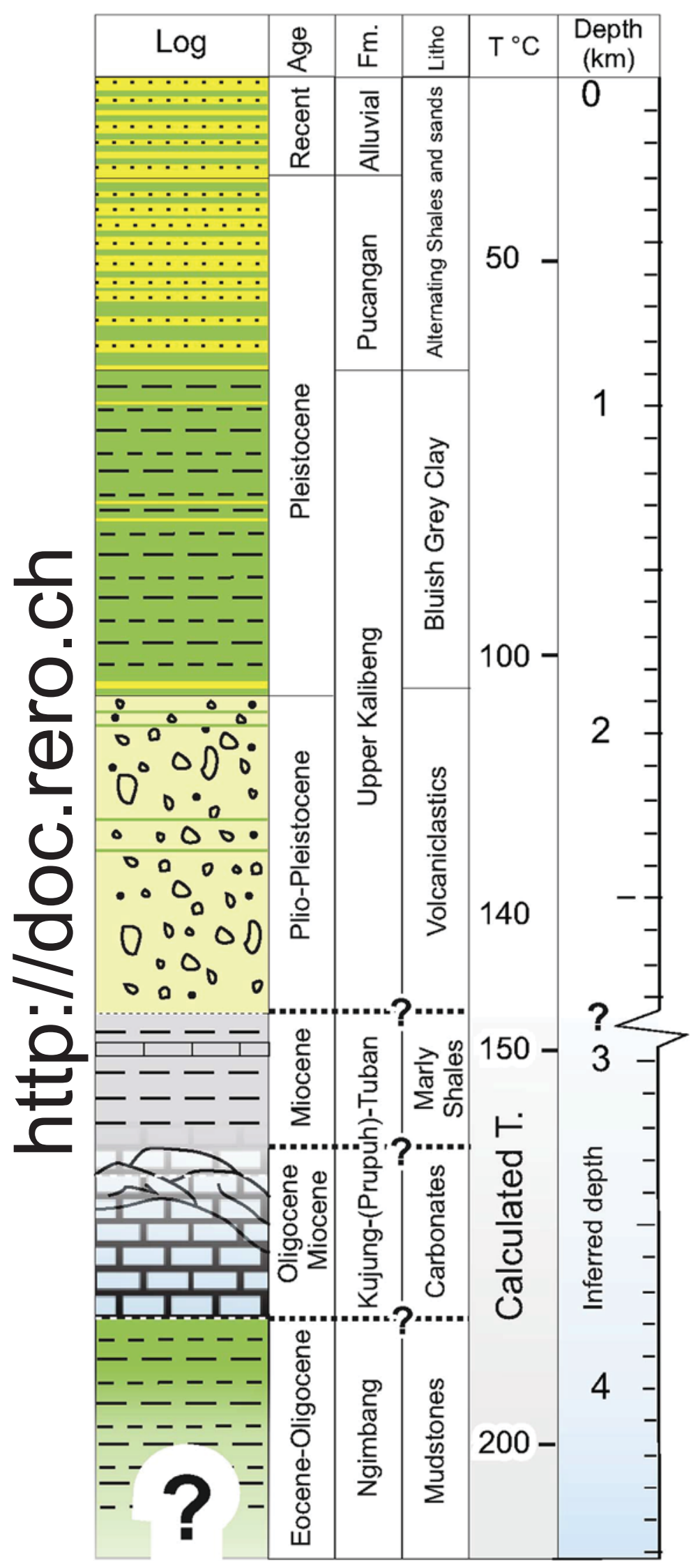

Fig. 5. Schematic log summarising the stratigraphy at Lusi site. The thin carbonates in the Tuban Formation could represent the youngest samples consisting of scleractinian corals of our collection and correspond to reefal facies reported in the literature (e.g., Sharaf et al., 2005). The scheme is adapted from Mazzini et al. (2012) and updated using data from the present publication. Question marks and dashed lines refer to uncertainties to locate the boundaries between the formations that have not been drilled (unlike the top $2833 \mathrm{~m}$ ). See more info in the introduction. These boundaries are inferred based on seismic data interpretation.

is of much better quality. Below Lusi the seismic signal is in fact disturbed with discontinuous and chaotic reflectors which impair the immediate stratigraphic interpretation of the units not penetrated by the BJP-1 well. However, by using the proposed composite line through PRG-1 well, several horizons defined using seismostratigraphic criteria (facies and geometry such as onlaps and truncations) can be traced back to the Lusi region with relatively high level of confidence. Overall, this allowed us to recognize a stratigraphic unit sandwiched between the volcanoclastic deposits of the Upper Kalibeng Formation and the OligoMiocene carbonates. This has been interpreted as the transgressive shales of the Tuban Formation (Fig. 6) onlapping and partly blanketing the underlaying carbonate buildups structures. The surface separating the Upper Kalibeng Formation and the Tuban Formation is marked by a clear angular unconformity of seismic reflectors (Fig. 6) indicating its erosional nature. Above the carbonate structure in correspondence of the BJP-1 the preserved thickness of Tuban Formation is ca. $420 \mathrm{~m}$ while it reaches only few meters $(<10-15 \mathrm{~m})$ above the structure penetrated by the PRG-1 well. This interpretation is consistent with the finding of shallow-water red algal remains dated at 16 Ma in the PRG-1 well (Kusumastuti et al., 2002) above the carbonates. Based on our seismic interpretation, the Tuban Formation thins towards the ENE. These data also suggest a syn-tectonic deposition, possibly related to a tilting of the carbonate platform ridge which induced its uplift in the ESE (i.e. in the Porong region) and subsidence to the WSW (i.e. at Lusi locality). The shallow-water deposits recorded in the Tuban Fm in the PRG-1 well is consistent with the finding of coeval planktonic foraminifera-bearing deposits described in this study, attesting the progressive transgressive (i.e. deepening) of the depositional environment recorded by the Tuban Formation. Below this unit, the top of OligoMiocene carbonates, as well as their inferred base can be traced from one well to the other, showing most likely the presence of the Prupuh Unit (Early Miocene) resting on the more laterally continuous Oligocene Kujung carbonates. Below the carbonates, transparent seismic facies resting on a high-amplitude tabular reflector are interpreted as the continental shales and possibly lacustrine and marine carbonates associated with the Ngimbang Formation as reported to be present in the region by various authors (Mudjiono and Pireno, 2002; Lelono and Morley, 2011; Satyana and Purwaningsih, 2003).

We compared the available regional stratigraphic information with the $2 \mathrm{D}$ seismic calibrated with check-shot derived velocity data. The depths of the formations below Lusi are estimated as follow: top Tuban Formation $\sim 2840 \mathrm{~m}$, top Kujung Formation (including the Prupuh Unit) $\sim 3260 \mathrm{~m}$, top Ngimbang Formation $\sim 3850 \mathrm{~m}$ true vertical depth. The seismic data examined do not allow for confident identification of the base of the Ngimbang Formation in the area of the BJP-1 well.

\section{Implications and conclusions}

The dating of carbonates within the Lusi erupted mud breccia and the interpretation seismic profiles reported herein have several implications. These can be summarized as follows:

1) Our findings provide additional information regarding the regional stratigraphy indicating that the volcanoclastic sediments are overlying a succession of carbonates, which age spans from Miocene to Eocene. 
A

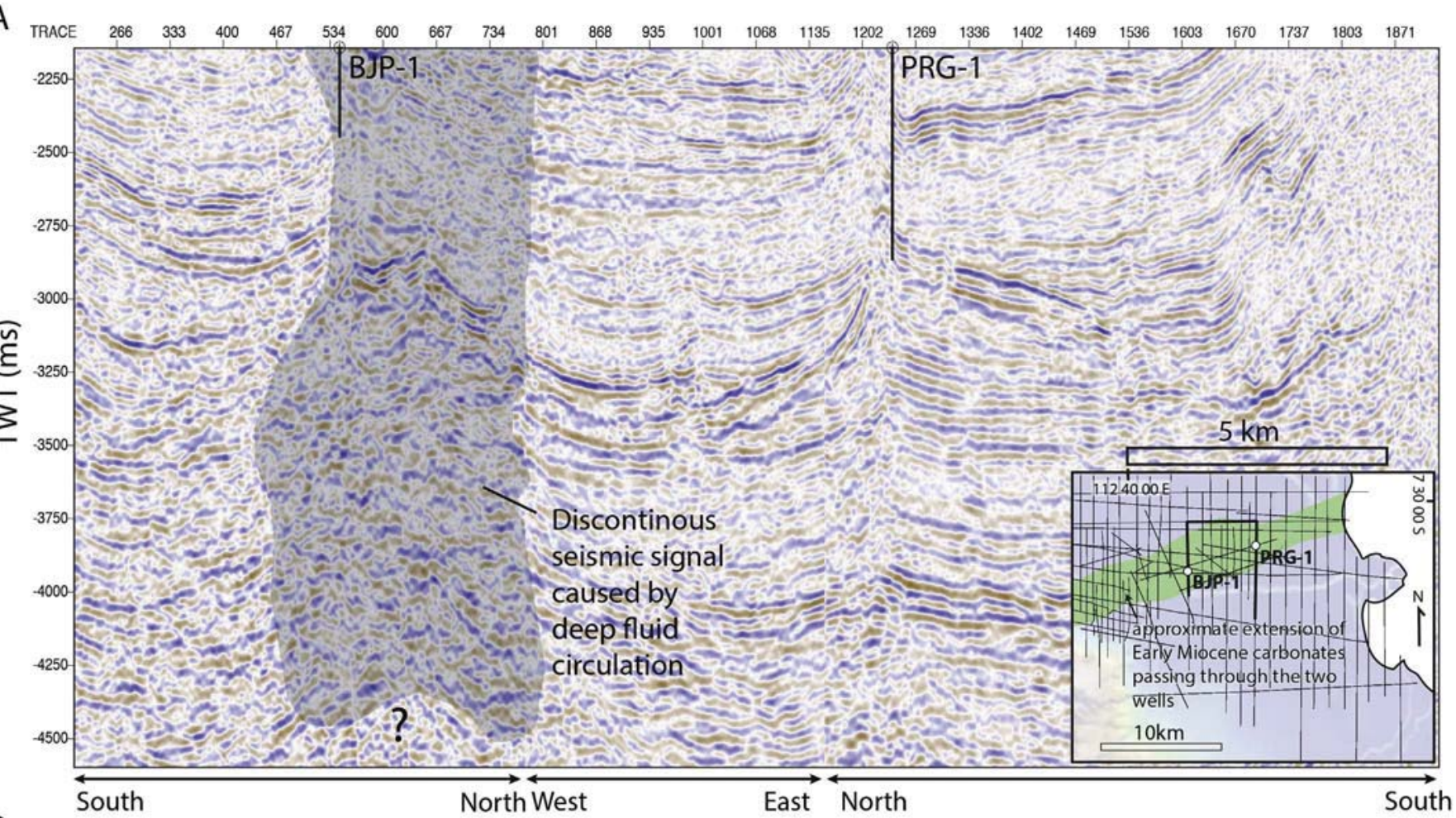

B

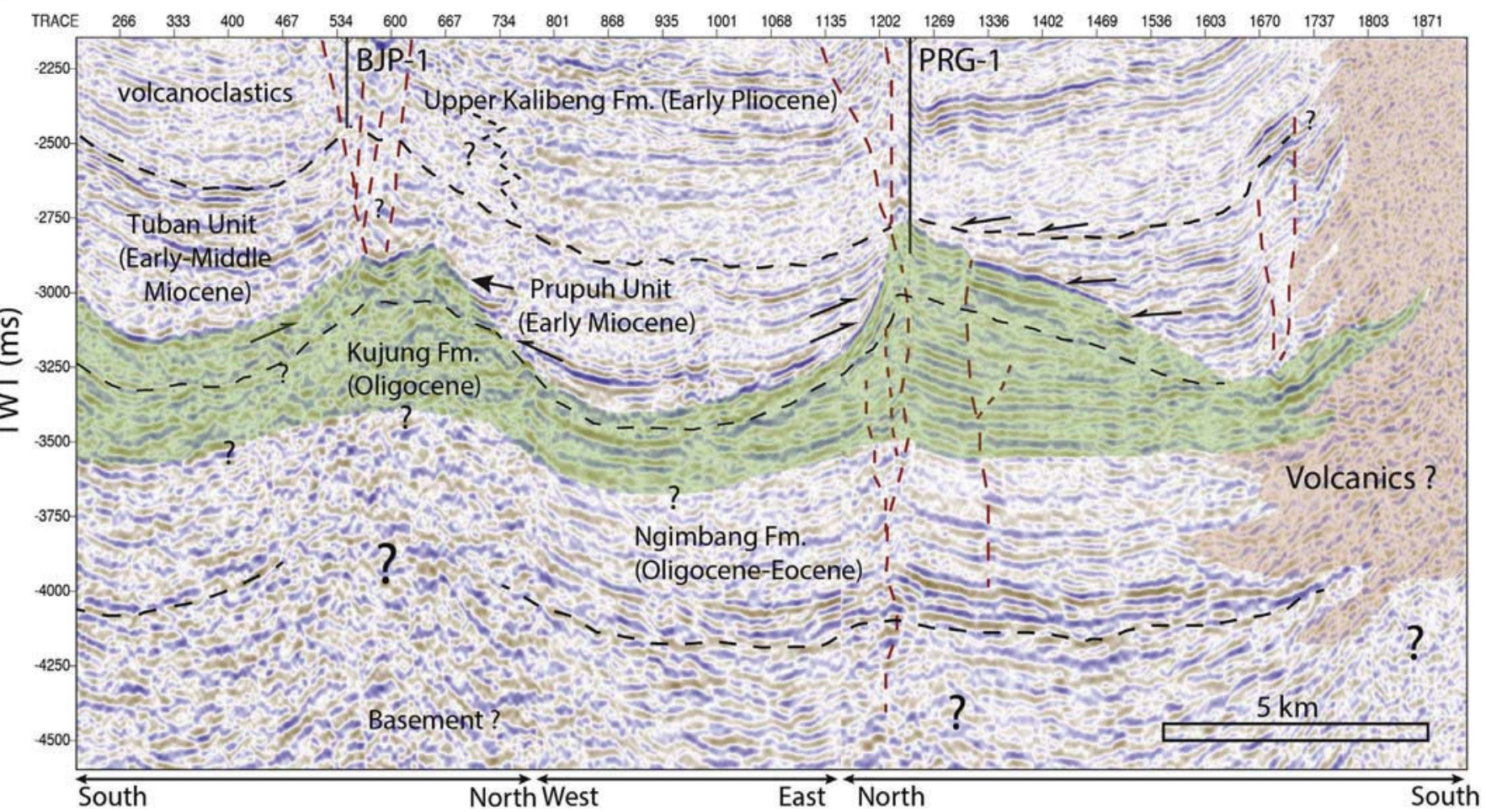

Fig. 6. A) Composite 2D seismic line crossing the wells PRG-1 and BJP-1 (for location of the seismic line see inset map) showing the architecture of the deep sedimentary succession in the area immediately above and below the Oligo-Miocene carbonates. In the BJP-1 area, corresponding to the gray zone, is visible the highly-disturbed seismic signal likely caused by the effect of deep fluid circulation associated with the predisposing conditions resulted in the Lusi eruption. B) The composite section allows the stratigraphic correlation between the two wells. Even when the signal is disturbed (BJP-1 area) it is possible to recognize (based on reflector geometries and seismic unit architecture) and to extrapolate the key stratigraphic units which, from top to bottom include: the Upper Kalibeng Formation, Tuban Formation, Kujung Formation (including the Prupuh Unit), the Ngimbang Formation. The basement is likely present at the base of the section. Note the important thickness change of Tuban Formation in the two areas indicating a possible topographic and tectonic control during the deposition of this unit.

2) These carbonate clasts were brecciated through the Lusi conduit and brought to the surface during the eruptive activity. Indeed the occurrence of carbonate clasts with a minimum age of $23.77 \mathrm{Ma}$ indicates that the source of some of components extends to the base of the Kujung Formation (Late Oligocene to Early Miocene)(e.g., Ardhana, 1993; Satyana, 2005; Sharaf et al., 2005), This finding 


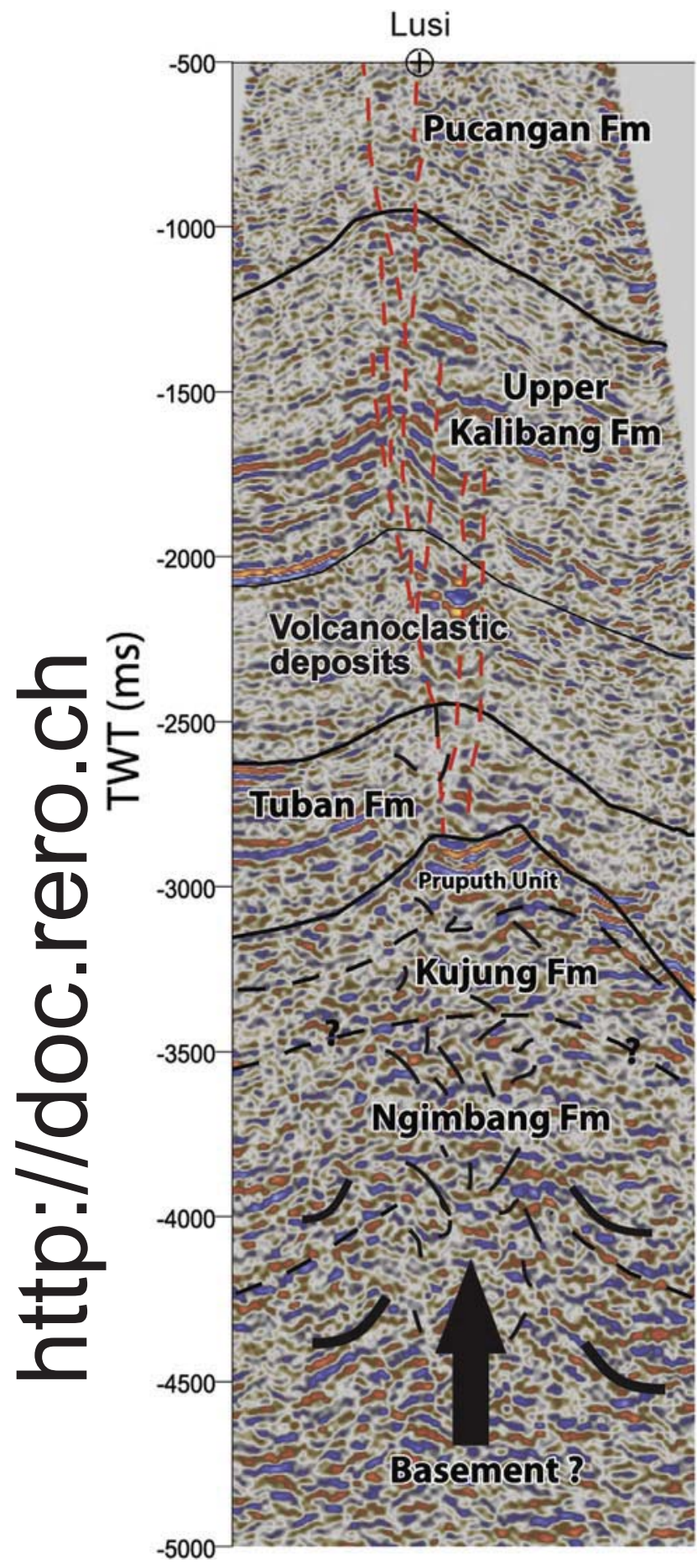

Fig. 7. Seismic line collected in the 80 's below the Lusi eruption site with schematic formations boundaries. Some of the features observed inside the formations are included. The image highlights that before the eruption occurred significant overpressure had to be present at great depth (e.g in the Ngimbang Formation). This would be indispensable to bring to the surface clasts of deep platform carbonate from the Kujung Formation that, at this depth, is typically not overpressured, and also clasts from the Ngimbang Fm. Faults migrating towards the surface were already present at the time of the seismic data collection. Modified from Moscariello et al. (2017). “?” indicates uncertainty in interpretation.

\section{Folded upper units affected by intense fracturing and faulting brittle deformations}

\section{Brecciated and fluid-rich units}

\section{Overpressure present below the carbonates prior to eruption}

supports previous geochemistry results (Mazzini et al., 2012), which indicated that the fluids source and the Lusi plumbing system are indeed deeper than the Kalibeng formation. Results support a scenario where fluids and rock fragments are moving from great depth since the very beginning of the eruption. This implies that not only the Kalibeng Formation plays a key role in sourcing sediment and fluids but also deeper units are part of the plumbing system.

3) The presence of both the Oligocene Kujung Formation and the Miocene Tuban Formation at the same site provides insights into the paleogeography of the area. Facies encountered in the older clasts indicates an off-reef, pelagic depositional setting, whereas the clasts exhibiting younger ages are from a shallow-water, reefal depositional environment. This result implies a superposition of two lithologies denoting different depositional conditions, confirming progradation and/or facies transitions that are possibly fault controlled (Matthews and Bransden, 1995; Sharaf et al., 2005).

4) The interpretation of seismic data indicates that the bottom part of BJP-1 well is within the volcanoclastic deposits of the Upper Kalibeng Formation. Further, this unit is overlying a $420 \mathrm{~m}$ thick marly-shale package of the Tuban Formation. The (reefal?) carbonates (supposedly Purpuh Unit, as part of the Kujung Formation) are encountered at a depth of $3260 \mathrm{~m}$. Ultimately the bottom part of the Kujung Formation is encountered at $3850 \mathrm{~m}$, overlaying the Ngimbang Formation.

5) The deposits close to the bottom of BJP-1 well have been commonly associated with the carbonates encountered at the bottom of the PRG-1 well. Our seismic data provide a new interpretation of the 
carbonate stratigraphy below Lusi and the PRG-1 well. Results show that the formation at the bottom of PRG-1 well, interpreted here to belong to the Kujung Formation, is not stratigraphically equivalent to that commonly believed to be just below the bottom of BJP-1 well where $420 \mathrm{~m}$ of Tuban Formation are suggested to be present before finally reaching the Kujung Formation.

6) The presence of Eocene carbonates gives hints about the Lusi dynamics. The Kujung carbonates are the common reservoir units in the prolific offshore East Java Basin. The lower and older portions of Kujung Formation are typically not overpressured (Kusumastuti et al., 2002; Sharaf et al., 2005; Ramdhan et al., 2013). Since these rock fragments are present at Lusi site from the early stages of the Lusi eruption, we can infer that additional overpressure was required from deeper units (likely in the Ngimbang Formation) to eject these clasts all the way to the surface (Fig. 7). The scenario is also consistent with the model depicted by Mazzini et al. (2012) that highlighted the presence of mantellic fluids expelled at Lusi (hence the definition of sediment-hosted geothermal system) likely migrating through the deeply sited Ngimbang Formation below $3.8 \mathrm{~km}$. Corroborating results have been recently published by Fallahi et al. (2017) where tomography studies clearly highlighted that the Arjuno-Welirang neighbouring volcanic complex is connected with Lusi at $\sim 4.5 \mathrm{~km}$ depth.

The finding of early clasts of an age equivalent to that the Ngimbang Formation, recorded in the present study, provides further evidence for this scenario.

\section{Acknowledgements}

The work was funded by the European Research Council under the European Union's Seventh Framework Programme Grant agreement $n^{\circ}$ 308126 (LUSI LAB project, PI A. Mazzini). We acknowledge the support from the Research Council of Norway through its Centers of Excellence funding scheme, Project Number 223272 (CEED). BPLS is thanked for their support during the field operations. Analyses were supported by a grant of the Swiss National Science Foundation (Grant $N^{\circ} 133771$ to E. Samankassou). The authors would like to thank Lapindo Brantas, Indonesia for providing access to the subsurface data. We are grateful to the Editor and two anonymous Reviewers who made insightful comments and contributed to improve the quality of the manuscript. The interpretation and model presented in this paper reflect solely the view of the authors at the stage of the manuscript preparation. Schlumberger is thanked for granting access to the Petrel platform for seismic interpretation.

\section{Appendix A. Supplementary data}

\section{References}

Akhmanov, G.G., Premoli Silva, I., Erba, E., Cita, M.B., 2003. Sedimentary succession and evolution of the Mediterranean Ridge western sector as derived from lithology of mud breccia clasts. Mar. Geol. 195, 277-299.

Ardhana, W., 1993. A depositional model for the Early Middle Miocene Ngrayong Formation and implications for exploration in the East Java basin. IPA 22nd Annu. Conv. Proc. 395-443 v. IPA93-1.1-020.

Ellis, B.F., Messina, A., 1949. Catalogue of Foraminifera. Am. Mus. Nat. Hist.. http:// www.micropress.org/em/about.php.

Fallahi, M., Obermann, A., Lupi, A., Karyono, K., Mazzini, A., 2017. The Lusi eruption plumbing system revealed by ambient noise tomography. J. Geophys. Res. http://dx. doi.org/10.1002/2017JB014592.

Gennari, G., Spezzaferri, S., Comas, M.C., Rüggeberg, A., Lopez-Rodriguez, C., Pinheiro, L.M., 2013. Micropaleontological characterization of the mud breccia from three mud volcanoes in the West Alboran Basin: implications for age variation of the source sediments and mud volcanic activity. Mar. Geol. 339, 83-95. http://dx.doi.org/10. 1016/j.margeo.2013.04.002.

Giresse, P., Loncke, L., Huguen, C., Muller, C., Mascle, J., 2010. Nature and origin of sedimentary clasts associated with mud volcanoes in the Nile deep-sea fan. Relat. fluid venting Sediment. Geol. 228, 229-245. http://dx.doi.org/10.1016/j.sedgeo.2010.04.014.
Israelson, C., Spezzaferri, S., 1998. Strontium isotope stratigraphy from ODP Sites 918 and 919. In: In: Larsen, H.C., Saunders, A. (Eds.), Proceedings ODP, Scientific Results, vol. 152. pp. 233-242 College Station, TX (Ocean Drilling Program).

Istadi, B.P., Pramono, G.H., Sumintadireja, P., Alam, S., 2009. Modeling study of growth and potential geohazard for LUSI mud volcano: East Java, Indonesia. Mar. Petroleum Geol. 26, 1724-1739.

Karyono, K., Obermann, A., Lupi, M., Masturyono, M., Hadi, S., Syafri, I., Abdurrokhim, A., Mazzini, A., 2016. Lusi, a clastic dominated geysering system in Indonesia recently explored by surface and subsurface observations. Terra Nova. 29, 13-19. http://dx.doi.org/10.1111/ter.12239.

Kusumastuti, A., Darmoyo, A.B., Wahyudin, S., Sosromihardjo, S.P.C., 2000. The wunut field: Pleistocene volcaniclastic gas sands in East Java. October 1999 In: Proceedings, Indonesian Petroleum Association, Twenty Seventh Annual Convention and Exhibition. Indonesian Petroleum Association 1, Jakarta, pp. 195-216.

Kusumastuti, A., Van Rensbergen, P., Warren, J.K., 2002. Seismic sequence analysis and reservoir potential of drowned Miocene carbonate platforms in the madura strait, East Java, Indonesia. AAPG Bull. 86 (2), 213-232.

Lelono, E.B., Morley, R.J., 2011. Oligocene Palynological Succession from the East Java Sea: Geological Society. vol. 355. Special Publications, London, pp. 333-345.

Lupi, M., Saenger, E.H., Fuchs, F., Miller, S.A., 2014. Corrigendum: Lusi mud eruption triggered by geometric focusing of seismic waves. Nat. Geosci. 7, 687-688.

Matthews, S.J., Bransden, P.J.E., 1995. Late cretaceous and cenozoic tectono-stratigraphic development of the East Java Sea basin, Indonesia. Mar. Petroleum Geol. 12 (5), 499-500.

McArthur, J.M., Howarth, R.J., Bailey, T.R., 2001. Strontium isotope stratigraphy: LOWESS Version 3. Best-fit line to the marine Sr-isotope curve for 0 to $509 \mathrm{Ma}$ and accompanying look-up table for deriving numerical age. J. Geol. 109, 155-169.

Mazzini, A., Etiope, G., Svensen, H., 2012. A new hydrothermal scenario for the 2006 Lusi eruption, Indonesia. Insights from gas geochemistry. Earth Planet. Sci. Lett. 317, 305-318.

Mazzini, A., Scholz, F., Svensen, H., Hensen, C., Hadi, S., 2017. The geochemistry and origin of the hydrothermal water erupted at Lusi, Indonesia. Mar. Petroleum Geol. http://dx.doi.org/10.1016/j.marpetgeo.2017.06.018.

Mazzini, A., Svensen, H., Akhmanov, G.G., Aloisi, G., Planke, S., Malthe-Sorenssen, A., Istadi, B., 2007. Triggering and dynamic evolution of the LUSI mud volcano, Indonesia. Earth Planet. Sci. Lett. 261, 375-388.

Miller, S.A., Mazzini, A., 2017. More than ten years of Lusi: a review of facts, coincidences, and past and future studies. Mar. Petroleum Geol. http://dx.doi.org/10. 1016/j.marpetgeo.2017.06.019.

Moscariello, A., Do Couto, D., Mondino, F., Booth, J., Lupi, M., Mazzini, A., 2017. Genesis and evolution of the Watukosek fault in the Lusi area (East Java) from 2D seismic interpretation and attribute analysis. Mar. Petroleum Geol. http://dx.doi.org/10. 1016/j.marpetgeo.2017.09.032.

Mudjiono, R., Pireno, G.E., 2002. Exploration of the north madura platform, offshore East Java, Indonesia. In: Proceedings, Indonesian Petroleum Association $28^{\text {th }}$ Annual Convention \& Exhibition, pp. 20.

Premoli Silva, I., Erba, E., Spezzaferri, S., Cita, M.B., 1996. Variation in age of the diapiric mud breccia along and across the axis of the mediterranean ridge accretionary complex. Mar. Geol. 132, 175-202.

Ramdhan, A.M., Hakim, F., Hutasoit, L.M., Goulty, N.R., Sadirsan, W., Arifin, M., Bahesti, F., Endarmoyo, K., Firmansyah, R., Zainal, R.M., Gulo, M.Y., Sihman, M., Suseno, P.H., Purwanto, A.H., 2013. Importance of understanding geology in overpressure prediction: the example of the East Java basin. In: Presented at the 37thProceedings. Annual Convention and Exhibition of the Indonesian Petroleum Association IPA13-G-152.

Ride, W.D.L., Cogger, H.G., Durpuis, C., Kraus, O., Minelli, A., Thompson, F.C., Tubbs, P.K., 2012. International Code of Zoological Nomenclature, fourth ed. . http://www. iczn.org/iczn/index.jsp.

Rögl, F., 2012, Globigerina triloba Reuss 1850, Designation of a neotype: Annalen des Naturhistorischen Museums in Wien, Austria, v. 114, p. 179-191.

Satyana, A. H., 2005, Oligo-Miocene Carbonates of Java, Indonesia: Tectonic-Volcanic Setting and Petroleum Implications: Proceedings, Indonesian Petroleum Association, v. Thirtieth Annual Convention \& Exhibition, August 2005, IPA05-G-031, p. 217-249.

Satyana, A.H., Darwis, A., 2001. Recent significant discoveries within Oligo-Miocene carbonates of the East Java basin: integrating the petroleum geology. In: Proceedings Indonesian Association of Geologists (IAGI) $30^{\text {th }}$ Annual Convention and $10^{\text {th }}$ Geosea Regional Congress, pp. 42-46.

Satyana, A.H., Purwaningsih, M.E.M., 2003. Geochemistry of the East Java basin: new observations on oil grouping, genetic gas types and trends of hydrocarbon habitats. In: Proceedings Indonesian Petroleum Association, $29^{\text {th }}$ Annual Convention and Exhibition, October 2003

Sawolo, N., Sutriono, E., Istadi, B.P., Darmoyo, A.B., 2009. The LUSI mud volcano triggering controversy: was it caused by drilling? Mar. Petroleum Geol. 26, 1766-1784.

Sharaf, E., Simo, J.A., Carroll, A.R., Shields, M., 2005. Stratigraphic evolution of OligoceneMiocene carbonates and siliciclastics, East Java basin, Indonesia. AAPG Bull. 89, 799-819.

Spezzaferri, S., Kucera, M., Pearson, P.N., Wade, B., Rappo, S., Poole, C., Morard, R., Stalder, C., 2015. Fossil and genetic evidence for the polyphyletic origin of the planktonic foraminiferal genus Globigerinoides and the description of the new genus Trilobatus. PLoS One 10 (5), e0128108. http://dx.doi.org/10.1371/journal.pone.0128108.

Spezzaferri, S., Olsson, R.K., Hemleben, C., 2017. Taxonomy, biostratigraphy and phylogeny of Oligocene and lower Miocene Globigerinoides and Trilobatus. In: Cushman Foundation for Foraminiferal Research. vol.46. Special Publication, pp. 269-306.

Turco, E., Iaccarino, S.M., Foresi, L.M., Salvatorini, G., Riforgiato, F., Verducci, M., 2011. Revisiting the taxonomy of the intermediate stages in the Globigerinoides_Praeorbulina lineage. Stratigraphy 8 (2-3), 163-187.

Wade, B.S., Pearson, P.N., Berggren, W.A., Pälike, H., 2011. Review and revision of Cenozoic tropical planktonic foraminiferal biostratigraphy and calibration to the geomagnetic polarity and astronomical time scale. Earth-Science Rev. 104, 111-142. 